\title{
THE DIFFERENT TYPES OF DELINQUENT BEHAVIOR IN THE HOSPITALITY INDUSTRY: CASE STUDY FROM GREECE
}

\author{
Polyxeni Moira $^{1}$--- Dimitrios Mylonopoulos ${ }^{2}$--- Panagiota Vasilopoulou ${ }^{3}$ \\ ${ }^{1,2}$ Technological Education Institute of Piraeus/Greece, Department of Business Management \\ ${ }^{s}$ Hellenic Open University
}

\begin{abstract}
Delinquent behavior in hotels is well known both to the hotel industry professionals as well as to the customers. The particularity of hotels being considered to provide a "hospitable" and discreet environment, tranquility and security, prevents the disclosure of the incidents of delinquency that occur in them. In Greece, as well as abroad, despite the fact that delinquent acts are known to occur constantly in hotels, nonetheless the facts do not easily go public, and there seems to exist no hotel department responsible for systematically and 'scientifically' managing the cases in question. This study aims to record and classify the incidents of delinquent behavior occurring in the Greek hospitality industry through primary research conducted at hotels throughout Greece. In parallel, a record was created, of the way the incidents were handled, who was the person that managed such incidents, the existence -or not-of staff training, the employment of security personnel, whether the assistance of the police was required or not, communication management of the incidents, etc. The survey was conducted by distributing questionnaires in combination with structured interviews with hotels' executives. The results demonstrate the existence of all kinds of delinquency such as theft, drug use/ abuse, prostitution, fraud, domestic violence, etc. Due to the lack of systematic research in Greek hotels for the phenomena of delinquent behavior and ways of their management, combined with the location, the type, the seasonality and the size of the enterprise, a new survey is proposed to be conducted by means of a targeted research involving scientists originating from the field of social and legal sciences, management, psychology, etc. in order to provide a comprehensive picture of the problem and methodology to tackle the issue.
\end{abstract}

Keywords: Hotel, Hotel delinquency, Hotel safety and security. 


\section{INTRODUCTION}

Delinquency is directly related to hotel accommodation since antiquity till today (Salles, 1998). Delinquency is a broader concept than crime and results from the circumvention and bypass of the legal framework adopted by and is in force by both the society and the State. By the term delinquency or delinquent behavior, is characterized the type of behavior which is not only criminal but is also contrary to other rules or regulations that bring oneself milder punishment.Is should also be noted that the term deviation generally refers to forms of behavior, which are not entirely socially acceptable, but they do not necessarily constitute a violation of a legal rule e.g. drug use, vagrancy, absence from school (Nova-Kaltsouni, 2001).

Therefore, the term delinquent behavior along with its various components and various degrees or manifestation expresses the deviation and aberrant behavior of individuals. This type of behavior does not always take the form of a criminal offence, andto a large extent it is not disclosed or reported by the victims, the families of the perpetrators and the social environment (Mavroyiannis, 2006).

The phenomenon ofdelinquentbehavioris defined anddetermineddifferently depending on thetime, placeandsocial system.Anact whichconstituted aviolationthe previouscentury or evena fewdecadesago, thereis no certainty that it is still aviolationnowadayse.g.banofliquorin the eraof Prohibitionin the U.S.But even geographically,a phenomenoncompared toother countries, it might be treated differently.Forexample, the useof drugssuch as marijuanaand hashish, is legal in coffee shopsin the Netherlands (Ossebaard and van de Wijngaart, 1998; Korf, 2002) while in Greeceis yet another example ofcriminal behavior.

In some countries, prostitution is an acceptable institution, which actually supports tourism,as manytourists are travelingin these countries, their main purpose being atype of tourismcalled "sex tourism." Therefore, what constitutes unlawful conduct cannot be studied separately, nor be studied outside the social context within which it takes place, because the historical, social, economic and political conditions arethose thatdetermine whichcustoms ormoralsorhuman behavior,in general, are being designatedby the legislature andthe criminallaw aspunishableacts (Farsedakis, 1996; Giddens, 2002; Hughes and Kroehler, 2007).

\section{HOTEL DELINQUENCY}

As hoteldelinquency, it is designated whatever occurs at any site (room, restaurant, lobby, public areas, swimming pool, gym, spa, etc.) either by the employee or by the customer, or any user-consumer of the hotel product-service. The breadth of hotel delinquency ranges from refusal to pay a price for the consumption of products or services, pilferage from the hotel, disorderly conduct/disturbance of the peace, to actual crime.

In Greece, aswell as abroad,even though delinquentacts areknown tooccurconstantly in hotels,the incidents however are noteasily exposed and there seems to be lacking a hotel department thatmanages them in asystematicand 'scientific' manner. There is littleresearch made on thenature and the extentof delinquencyin hotelsin Greece. On the other hand, abroad, an effort 
to systematically record all forms of delinquency there seems to be made both in the hospitality and the tourism industry in general (Enz, 2009) and to efficiently manage such incidents by the means of employing security specialists. (Sennewald, 1985; Nalla and Newman, 1990; Gill, 1994; Borodzicz, 1996; Simonsen, 1996; Manunta, 1999; Donald, 2001).

A significant part of tourism industry, in which the Hospitality and Food \& beverage industries are included, belong to the so-called, by the researchers, night economy / "economy of the night"' in the sense that their main bulk of work occurs after nightfall (Hoel and Einarsen, 2003). Thus it focuses considerably on alcohol consumption and often appeals to younger customers. These particular characteristics of the clientele result to the enterprises being frequently exposed to delinquent behavior. (Hobbs et al., 2002). What is more, a part of this industry provides environments that support sex or sexual activities resulting in a high rate of worker exposure to delinquent behavior by the customers.Especially since the hotel industry emphasize on the "friendliness" of the hospitality industry nature, hotels aim to make customers feel that they are at their second home (Gill et al., 2002). Emphasis on security and privacy, as well as discretion, elements that is often difficult to be reconciled. The ambience of the hotel is designed to make quests feel 'at home' in spite of the commercial and public nature of the place. But it is this ambiguity between the private and public standards and behaviors that may be contributing to the increased delinquent behavior not only in hotels, but in bars and hotel restaurants as well.

Meanwhile, the area of the hotel is very "sensitive," and any offending behavior especially if disclosed, may cause fear, insecurity, loss of reputation of the unit and eventually drop in bookings.

According to surveys conducted in the United Kingdom violence and/or sexual harassment related incidents tend not to be publicized. (Scott, 1998; HSE, 2001). Generally, it is observed that there is a tendency to"non-disclosure" of events andsettlements ofdelinquentbehavior andother incidents from within.InGreece,there are very fewincidentsthat seethe light of dayandif doneso,this applies only to incidentsfor which police assistance was necessary.Andin such cases, strenuous efforts are madeto ensure that thepublicity is going to last only for a fewdays.This reactionisjustified.The "public image" of eachhotel unit andthe sense of securitythat inspires to its guestsiscritical to business.

\section{THE DELINQUENT BEHAVIOR OF CUSTOMERS}

In 1994, Christopher Lovelock introduced the term "Jaycustomer" referring to customers who behave purposefully in a bad way, demonstrate aggressive behavior, causing problems in the business, employees and other customers (Lovelock and Wirtz, 2010). This was the trigger for a series of studies on "inappropriate customer behavior" (Strutton et al., 1994), the vandalism from customers (Levy-Leboyer, 1984; DeMore et al., 1988), deviant customer behavior (Moschis and Cox, 1989; Fullerton and Punj, 1997; 2004; Tonglet, 2001), problematic customers (Bitner et al., 1994), the manifestation of violence from clients (Boyd, 2002; Farrugia, 2002), the formulation of 
illegal complaints (Jacoby and Jaccard, 1981; Kowalski, 1996)sand forced consumption (O'Guinn and Faber, 1989; Hirschman, 1992).

Customers who manifest delinquent behavior are unwanted by tourism enterprises. Inthe event ofnon-desired behavior, companies trytoprevent (Lovelock and Wirtz, 2010) ormanage itrationally (Webster, 1994; Berry, 1995; Schneider and Bowen, 1995; Wiersema, 2001; Harris and Reynolds, 2004); (Robinette et al., 2000).

According to Love lock \& Wirtz these customers are classified into seven categories i.e. cheaters(the cheat),thieves(the thief),rule breakers (the rulebreaker),jingo(the belligerent), those involvedin adisagreement/fightwith memberstheir family(the family feuders), vandals (the vandals) and bad payers (the deadbeat) (Lovelock and Wirtz, 2010).

The Harris and Reynolds (2004) categorizedtheirdelinquentguests (jaycustomers)in the hospitality industry, restaurants and barsina)those whoexpressin writingany service complaintsandseeksome kind ofcompensation for"bad"servicesreceived, b) undesiredguests(noisy /annoyingkids, annoyingbehavior, criminal behavior(prostitution, drug use, etc.) and homeless people who use the premises and steal from customers) c) those who engage in vandalism and remove objects, of ten as souvenirs, d)those who deliberately cause problems for profit, e)vindictive customers (with violent behavior against persons or property), f) revilers, g)those exercisingphysical violence, and h) sex offenders (Harris and Reynolds, 2004), In (Lovelock and Wirtz, 2010).

But according to the International Labor Office there has been no study to systematicallyinvestigateand evaluatestrategies which could be implemented in order to prevent and reduce incidents of delinquency in the tourism industry (Hoel and Einarsen, 2003).

InGreecethere has been nosimilarresearchfor the types ofdelinquentbehaviorin the hotelindustry measuringtheincident rates, staff education, or the way that these incidents are managed bythecompany, etc.

\section{THE RESEARCH}

In an effort to determine the extent of delinquency in the hotel business, identify and classify the phenomena of delinquent customer behavior and how to overcome them, a research was conducted in hotels throughout Greece.

The research was conductedduring the periodMarch-April2012 whichis the period thatmost hotelsbegintheir operation.Interviewswere obtainedfrom managersof hotelsthroughoutGreece. The sample presented certain peculiarities, due to considerations of persons responsible to publicize - or not - such incidents. Forth is reason, the sample was "a sample of convenience." The respondents answered both in open and in closed questions. The questions raised concerned the occurrence of delinquency cases, the type, control mode, the person responsible for managingsuch incidents, the existence ornot of staff training, employment of security officers (Gill et al., 2002; Groenenboom and Jones, 2003) the involvementor not of thepolice, the handling ofthecommunication strategies regarding the incidentsetc.Eachinterviewlastedabout 6ominutes. 
Thereafter the encoded data is categorized, grouped and analyzed in order for the opinions in specific subjects to be measure, where this was possible. A total of 59 questionnaires and interviews were gathered, which correspond to 68 hotels. This occurred because some hotel chains responded to a questionnaire for all their units. By studying the questionnaires, the following findings arise in relation to the class, location and operation of the hotels surveyed.

The survey involved 21 women, which corresponds to $35.6 \%$ and 38 men which measure up to the percentage of $64.4 \%$. On the total, seven of them were aged 18 -25 years (11.87\%), 24 persons were aged $26-35$ years (40.68\%), 8 persons were aged $36-45$ years $(13.55 \%), 10$ person were aged 46-55 years $(16.95 \%)$ and 10 persons were aged 56 years and over $(16.95 \%)$.

Out of those surveyed 20 people had experience of 1-3 years (29.41\%), 24 subjects had 4-10 years of experience $(35.30 \%), 5$ persons had $11-15$ years $(7.35 \%)$ of experience, and 14 subjects had experience greater than 15 years (20.59 whereas 5 people $(7.35 \%)$ did not respond.

The 68 hotels in which the survey was conducted, covering in range all geographic regions of the Greek territory. The various hotel corporations cover all classifications (Rating in stars) and have plenty of visitors, Greeks as well as visitors from abroad. Of these, 34 operate on seasonal basis $(50 \%)$ and 34 function on continuous operation that is another $50 \%$ of the sample. In terms of ranking, one hotel was a luxury hotel (1.47\%), 14 hotels were rated 5 star (20.58\%), 27 hotels were 4 star $(39.70 \%), 16$ hotels were $3 \operatorname{star}(23.53 \%)$, 4 hotels was $2 \operatorname{star}(5.89 \%)$. In the survey also participated, a four-keys studio corporation (5.89\%), a traditional guesthouse $(1.47 \%)$ and a Boutique hotel (1,47\%).

As far as hotel capacity is concerned, 18 hotels were of the order of $10-30$ rooms (26.47\%), 7 hotels had 31-50 rooms (10.29\%), 19 hotels 51-100 rooms (27.94\%), 12 had 101-200 rooms $(17.6 \%)$ and 12 were more than 200 rooms (17.65\%)

The results are very interesting, as it has been highlighted by Patton (1990) and Stake (1995) as a much more in-depth study can occur of extreme and unusual circumstances rather than studying statistics and average values. Although it is not possible to fully generalize the research findings (except for those referring to hotels of same capacity and situated in large urban centers), though the results help in recording and understanding the types of offending behavior encountered in hotel accommodation and lead to possible solutions which would address them.

\subsection{The Grid of the Hotel Delinquency}

According to the survey, the term delinquency in relation to the hotel industry can have different manifestations in different directions and covers a wide range of offenses, from misdemeanors to felonies. In addition, the axes which can occur are numerous. According to the survey data it was found that delinquent behavior form a grid articulated to all actors in the hotel circuit (see Figure 1). 
FIGURE 1. The grid of delinquency in hotels

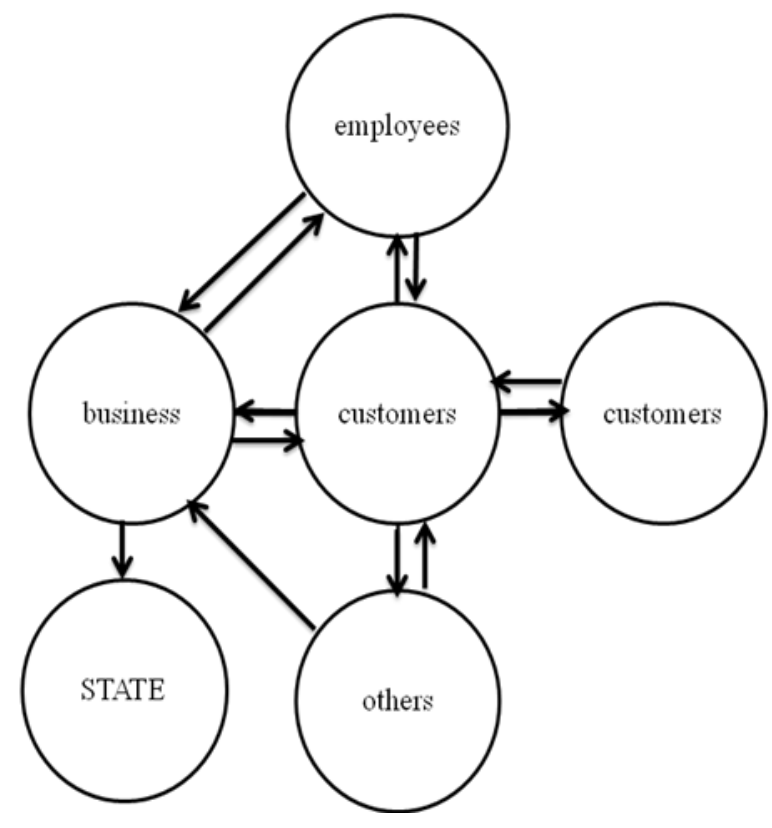

Editing \& presentation: The authors

Thus, according to the survey results, the delinquent behaviors as to their source, can be classified a) by the company to customers. (Inadequate safety measures, attempt to mislead customers in relation to the services or the price of the rooms, etc.) b) by employers to employees (mainly on the non-compliance with health and safety rules, failure to meet the financial commitments towards employees, imposing elastic contracts, black labor, refusal to pay accruals, etc.) c) by the employees to the company (theft, sabotage, loss of customers and therefore revenue loss due to incorrect treatment or operation on behalf of the staff, substance abuse, etc.) d) from employees to customers (theft, fraud, insulting, etc.), e) from customers to employees (sexual or other harassment, slander, deceit, etc.) f) from customers to other customers (prostitution, harassment, theft, substance abuse, etc.), g) from clients to the firm (deceit by various means e.g. fake food poisoning in order not to pay the bill, false declaration of injury and claiming compensation from the hotel, denial of payment, etc.) h) by the company to the state (waiving of taxes or employer tax contributions, not paying fines for noise pollution, lack of permit for musical instruments, music copyright, violations of environmental or urban regulations, etc.) and i) third party to the company (e.g. terrorism, damage during demonstrations, etc.)

\subsection{Delinquency of Hotel Customers}

By the interviews conducted in the 68 units, a great variety is recorded in the types of delinquent behavior in hotels. The delinquent behavior is recorded equally in both large and small hotel companies, although the severity and nature of the delinquent acts is related to the plant size, geographic location, customer type and other factors. 
Theft: The thefts have high incidence in hotels. According to bibliography, the incidence of theft, taking place in a hotel is distinguished in theft of valuables etc. objects of customers, theft of hotel items and stealing assets of officials (Gill et al., 2002). On the survey, 25 incidents of thefts were reported and recorded the first two types i.e. theft against customers and at the expense of the hotel. The value of the stolen goods ranged from minimal (e.g. stealing supplies from the stroller maid) to high value (cash, jewelry or computer). The thefts took place both inside the hotel (room service) as well as in public spaces (parking service, hotel beach, etc.).

In some cases, serious incidents e.g. on a large hotel complex, a person pretending to be a client opened up five rooms with a crowbar and took away valuables or in another case they removed personal belongings of customers from the breakfast room. The theft incidents are assessed depending on the value of the objects. So, theft of low value (consumables, ashtrays, etc) tends to be considered "routine" and tolerated as shrinkage (deficiencies / amortization). In several cases, the hotel administration avoids blaming the customers in order to avoid the loss of customers. The theft incidents involving objects of greater value are assessed accordingly. In these cases, the police is notified, taking care however not to give publicity and even in case of non-detection of person responsible, the company reimburses the customer with the return of stolen property. It is characteristic that the companies said that they prefer to compensate their clients rather than giving publicity to the intervention of the police.

To prevent such incidents, the company receives several measures, e.g. hiring security personnel, installation of security cameras, use of electronic keys / cards (that record access to each room) or control of incoming customers. By the interviews, it is recorded that such incidents are recorded mainly in large hotels, where the great number of customers makes them more impersonal and therefore vulnerable to theft and delinquency cases.

Another way to reduce the theft of small value objects such as towels, bathrobes etc. are hotels either to "facilitate" their customers by offering these items for sale, in low prices (Clarke and Homel, 1997) or take specific measures to identify stolen goods e.g. by RFID tagging (Radio Frequency IDedification tags) (Halverson, 2011). This way, in the event of disclosure of the "loss," the item may be charged and therefore facilitate the "legitimacy" of the client without simultaneously put the sensitive issue of "theft."

Drugs. The use of alcohol and illegal substances, such as drugs, undoubtedly, are part of the search for personal enjoyment and relaxation for some hotel guests who seek enjoyment in casual sex with other vacationers, or drinking too much alcohol, or using drugs (Hoel and Einarsen, 2003). Typically, substance abuse is associated with the occurrence of other delinquent behaviors such as disturbing the peace, insult of public morals, frustrations, prostitution, sexual harassment and various equipment damage either in public places or premises of the bedrooms. Research abroad, also shows significant drug use by employees of the hotel (Belhassen and Shani, 2012).

The investigation revealed that drug use or alcohol abuse occurs both in tourist hotels and in city hotels, with slight advantage in the resort hotel. The class, size and seasonality of the hotel did not seem to affect the manifestation of facts as the consumption of alcohol or drugs. 
Out of the nineteen (19) incidents described during the interviews, there was a client who after using drugs and alcohol wandered naked in the hotel, others who disrupt the peace or cause damage to the equipment of the hotel, or bothered other customers. In most cases, there was incident management with discretion so as not to interfere with the police and for the other customers not be bothered. In cases where drug use by employees during their service was found, the company proceeded to immediate dismissal of the employees for inappropriate behavior and taking preventive measures for non-recurrence of similar incidents (non-drug users recruit policy , conducting random blood tests, etc).

Particular and systematic preventive measures taken by any of the hotels participating were not registered on the survey.

Prostitution. The use of the hotel for prostitution is an extremely sensitive issue. Generally, it is a phenomenon that is carefully avoided mentioning as it implies defamation and the loss of customers for the hotel. Such incidents can lead to lawsuits by the police (Gill et al., 2002).

According to surveys conducted in London, two types of prostitution were shown: a) prostitutes to hang out in the exterior of the hotel and b) to arrive at the hotel escorting clients. In such cases, as the legality or otherwise of the attendant is not proved, the hotel show discretion and the topic is extremely sensitive

From the research 14 incidents were recorded. Typical, is the death of client during encounters with a prostitute. Inevitably, due to the nature of the incident, the police and the Emergency Center were contacted. The attendant after testifying to the police was released. The incident, following actions of the hotel, was not recorded and not made public by the media.

The investigation revealed that standard handling of such incidents from the hotel is to ask discreetly from prostitutes to leave the site. Discretion is imperative so as to not to disturb or offend other customers.

Sexual Harassment. Tourism by its nature encourages human interaction. It contains some elements that are indirectly related to human sexuality. During the holiday, sometimes creates a new social environment and conditions which may lead to behaviors of locals and tourists, much different and perhaps more flexible than usual. This is due to many reasons, like the fact that one is given the opportunity to act freely, as they are located in an unfamiliar social environment, strangers among strangers. Therefore, it is easier to overcome certain social inhibitions that limit one in their standard environment and can be expressed in ways that at least in some areas e.g. small communities would not pass unnoticed and unremarked (Moira et al., 2003).

Is a common phenomenon that of sexual harassment that occurs both from the customer towards the hotel staff (Boyd, 2002; Yagil, 2008) (Hoel and Einarsen, 2003), and (in rarer cases) by staff towards customers. From the survey data, there were recorded at least three incidents of harassment by a staff member. These cases were treated with discretion, but certain measures were to prevent their recurrence. These methods are the customer registration in an "undesirable customer" status/list, the use of security cameras, employees work in pairs so as to ensure their peace of mind and increase theirs sense of safety, etc. 
Fraud-refusal to pay. The most common forms of cheating the hotel business from the customer side are two. The first form of cheating is trying to use the services of the hotel without paying the price, with excuses such as losing money, money being stolen from the room during the stay in the hotel, credit card loss, etc. Indeed there is the term "Skipper" which used internationally to describe this type of customer (Theoharis, 2007). The survey also revealed that in seven cases, the quests leaving the hotel during the night without them going to the reception to settle their account. Such incidents are perhaps the highest occurrence incidences in delinquency on the part of customers.

The hotels try to limit such occurrences in several ways. The larger (usually) ones require prepayment of part or all of the overnight cost using cards or cash. Some hotels have stated that they have defined stricter procedures upon the arrival and departure of the clients, mainly for walk in customers for whom there is no history of previous residence. In many cases, payment of an additional sum as a guarantee for the extra consumptions of the customer is requested. If the consumptions of the customer are less than the deposit, then the guest is being reimbursed the excess amount on the departure from the hotel and not before.

This is an international practice, which for the customers who come from abroad is perfectly understandable and fully legitimate. But Greek customers, they still feel offended in many cases, and complain that hoteliers treat them as "suspected of escape" as characteristically one of the hoteliers' states in his interview.

The second form of customers trying to deceive the hotels is to claim compensation for theft of money, valuables or other personal items from their room, without such an event having actually occurred. Such incidents occur mostly in larger hotel units, where the "faceless" size makes it easier for the guests to report such incidents.

The hotels in such cases, are trying to reduce these losses by using electronic entry systems in rooms (mainly large), installing security cameras, employment of security guards the increased supervision/control measures by the reception, etc.

Disturbing the peace / breach of rules / acts of vandalism. In seasonally operation hotels which they are mainly addressed to foreign customers and operate exclusively with clients through tour operator, a numbers of incidents of disturbing the peace, drunkenness, damage to rooms by customers e.g. Broken beds, mirrors, etc were recorded.

The interviews raised several incidents, many of which were due to excessive consumption of alcohol or other substances by the quests. In such cases, all damages and disasters are recorded both in the rooms and public areas. In those cases there is record of damages and financial compensation is demanded from their clients on the hotels part.

Hotels that accept to accommodate groups of pupils or students during their vacations, plenty of customer complaints are recorded due to excess noise, due to drunkenness or altercation of pupils with customers, property damage of hotels etc. It is typical the refusal of a hotel guest to pay for their stay because of nuisance from noise. In this case the amount as agreed is paid by the head of the student group. The hotels usually treat these incidents with the existence of a clause 
in the contract for the payment of the cost of losing customers. Generally these events affect the image of the hotel and lead to loss of customers. In these cases the hotel should decide the type of clientele that they prefer as the hospitality students with delinquent behavior usually leads to loss of repeat customers, discontinuation of tour operators' contracts etc, which means cost to the hotel.

Also, there were recorded same incidents of protest from neighboring residents of the hotels premises due to heavy music volume where the restaurant area of the hotel held a wedding reception. In these cases, the police was allied, but after the necessary recommendations and reduction of the music volume the reception continued normally without any other impact on the hotel operations (of revenue for that matter). In a similar way, situations which involve various complaints of other customers e.g. for any lack of services, or they faces a problem on arrival etc. The company makes offers usually in services and hardly even in cash or any other goods (e.g. free entrance to the swimming pool, free drink, etc.) in order to appease them.

Interesting is the incident of the stay in a hotel suite of a foreign prisoner, who during his leave from prison, stayed in it for three days guarded. The hotel was aware of the quest's status and for this reason, the whole floor on which the room he was staying in, remained closed to other customers. The police had previously visited the hotel, and made thorough audits of both the safety of the prisoner and his exclusion from escaping, but also for the safety of other clients and staff. There were clear instructions to employees not to come into direct contact with the prisoner. When they had to clean the room, the customer, always accompanied by the police, was moved temporarily to another room. There were also strict orders not confirming the presence of the person and the police in the hotel premises and that the slightest comment should not be made both within and outside the site. Also, the hotel and the authorities decided to overlook the delinquent behavior of the customer (During his stay, he made excessive alcohol and substances abuse, and was visited by several ladies, always with the connivance of the police).

Domestic violence. Incidents of domestic violence (e.g. physical violence, psychological violence, sexual violence and rape) hardly see the light of publicity. Because of the sensitive nature of the matter, it requires tact, finesse and management by qualified personnel. The investigation revealed one case of domestic violence during their stay at the hotel. The wife asked the night auditor / receptionist to spend the night in another room because of a prior dispute with her husband. She claimed she could not stay with him because she was afraid for her physical integrity. There was also a protest by other tenants, residing in rooms nearby, for disturbing the peace. The following morning, the couple paid the bill for both rooms and departed without a problem. A year later, the hotel was contacted by the wife's lawyer and asked for the files of the hotel and the testimony of employees working that night that proved that there was a fight and she slept in another room, as his client had filed for divorce invoking of the incident. The handling of the case was made by the legal adviser of the company. 


\section{CONCLUSION}

The hotel sector appears to be particularly vulnerable to delinquency cases. On site all types of criminal behaviors are generated, which raises questions and concerns about their management by the hoteliers. The peculiarity of these phenomena combined with the need to ensure privacy and quietness of customers generates a reasonable debate on the management of such incidents. The need for privacy leads to management with a flexible and discreet manner, without resorting to the prosecuting authorities and an (intended) failure to disclose the incident to the media. The investigation found that there is in a large proportion, lack of skilled/qualified personnel to manage incidents of delinquency, which results in an empirical, random and fragmented way of handling.

Due to the lack of research in Greek hotels for the phenomena of delinquent behavior and the management procedures, in combination with the geographical location, type, seasonality and firm size, it is considered appropriate to conduct a targeted research involving scientists coming from the fields of social, legal sciences, management, psychology, etc. in order to provide a complete picture of the problem and a methodology to address it.

Funding: This study received no specific financial support.

Competing Interests: The authors declare that they have no competing interests.

Contributors/Acknowledgement: All authors contributed equally to the conception and design of the study.

\section{REFERENCES}

Belhassen, Y. and A. Shani, 2012. Hotel workers substance use and abuse. International Journal of Hospitality Management, 31: 1292- 1302.

Berry, L.L., 1995. On great service: A framework for action. New York: Free Press.

Bitner, M.J., B.H. Booms and L. Mohr, 1994. Critical service encounters: The employee's viewpoint. Journal of Marketing, 58: 95-106.

Borodzicz, E.P., 1996. Security and risk: A theoretical approach to managing loss prevention. International Journal of Risk, Security and Crime Prevention, 1(2): 131-143.

Boyd, C., 2002. Customer violence and employee health and safety. Work, Employment and Society, 16(1): 151-169.

Clarke, R.V. and R. Homel, 1997. A revised classification of situational crime prevention techniques. In: Lab, S.P., 1997, ed. Crime prevention at the crossroads Cincinnati, $\mathrm{OH}$ : Anderson.

DeMore, S.W., J.D. Fisher and R.M. Baron, 1988. The equity control model as a predictor of vandalism among college students. Journal of Applied Social Psychology, 18(1): 80-91.

Donald, C., 2001. Personal opinion: Repositioning security managers in organizations. Security Journal, 1(4): 75-76. 
Enz, K., 2009. Safety and security in U.S. Hotels, Cornell Hospitality Report, 9(13).

Farrugia, S., 2002. A dangerous occupation? Violence in public libraries. New Library World, 103(1180): 309-319.

Farsedakis, I., 1996. Criminology issues, Eds. Nomiki Vivliothiki, Athens (In Greek).

Fullerton, R.A. and G. Punj, 1997. Can consumer misbehaviour be controlled? A critical analysis of two major control techniques. Advances in Consumer Research, 24(1): 340-344.

Fullerton, R.A. and G. Punj, 2004. Repercussions of promoting an ideology of consumption: Consumer misbehaviour. Journal of Business Research, 57(11): 1239-1249.

Giddens, A., 2002. Sociology, (Tsaousis, G.G., transl.), ed. Gutenberg, Athens (in Greek).

Gill, M., C. Moon, P. Seaman and V. Turbin, 2002. Security management and crime in hotels. International Journal of Contemporary Hospitality Management, 14(2): 58-64.

Gill, M.L., 1994. Crime at work: Studies in security and crime prevention. Leicester: Perpetuity Press.

Groenenboom, K. and P. Jones, 2003. Issues of security in hotels. International Journal of Contemporary Hospitality Management, 15(1): 14-19.

Halverson, N., 2011. Washable RFID tags help catch hotel towel thieves, Discovery News. Available from http://news.discovery.com/tech/washable-rfid-tags-helpcatch-towel-thieves-1 10506.html.

Hoel, H. and St. Einarsen, 2003. Violence at Work in Hotels, Catering and Tourism. WP.211, Sectoral Activities Programme, Working Paper, International Labour $\begin{array}{llll}\text { Organisation } & \text { (ILO). } & \text { Genevar } & \text { Available }\end{array}$ https://www.escholar.manchester.ac.uk/uk-ac-man-scw:5b648.

Harris, L.C. and K.L. Reynolds, 2004. Jaycustomer behavior: An exploration of types and motives in the hospitality industry. The Journal of Services Marketing, 18: $339-357$.

Hirschman, E.C., 1992. The consciousness of addiction: Toward a general theory of compulsive consumption. Journal of Consumer Research, 19: 155-179.

Hobbs, D., P. Hadfield, S. Lister, S. Winslow and S. Hall, 2002. Bouncers: The art and economics of intimidation. Violence Research Programme, ESRC Economic and Social Research Council.

HSE, 2001. Catering industry must improve accident reporting rates. Health and Safety Executive. Available from www.hse.uk/press/e01102.htm.

Hughes, M. and C.J. Kroehler, 2007. Sociology. The basic concepts. (Christidis, G.E. trans.), Eds. Kritiki, Athens.

Jacoby, J. and J.J. Jaccard, 1981. The sources, meaning, and validity of consumer complaint behavior: A psychological analysis. Journal of Retailing, 57(34-23). 
Korf, D.J., 2002. Dutch coffee shops and trends in cannabis use. Addictive Behaviors, Bergamon, 27: 851-866.

Kowalski, R.M., 1996. Complaints and complaining: Functions, antecedents, and consequences. Psychological Bulletin, 199(2): 179-196.

Levy-Leboyer, C., 1984. Vandalism: Behaviours and motivations. New York: North Holland Printing.

Lovelock, C.H., 1994. Product plus: How product + service $=$ competitive advantage. McGraw-Hill: New York

Lovelock, C.H. and J. Wirtz, 2010. Services marketing. People, technology, strategy. 7th Edn.

Manunta, G., 1999. What is security? Security Journal, 12(3): 57-66.

Moira, P., A. Tsoumanis and D. Hadjilelekas, 2003. Sociology and Psychology of Tourism, Institute of Education / O.E.D.V., Athens (in Greek).

Moschis, G.P. and D. Cox, 1989. Deviant consumer behavior. Advances in Consumer Research, 16: 732-737.

Mavrogiannis, D.G., 2006. Child and Adolescent Delinquency: Pathogenic Causes Explaining the Decomposition of Institutional Socialization and the Effects of Exogenous Factors, Considerations, Greek Society for Strategic Studies, (in Greek)(36). Available from http://www.elesme.gr/elesmegr/main.htm.

Nalla, M. and G. Newman, 1990. The application of management model to security profession. Malaysian Safety and Security Journal: 18-25.

Nova-Kaltsouni, C., 2001. Forms of Deviant Behavior in Adolescence: The Role of Family and School, Eds. Gutenberg, Athens (In Greek).

O'Guinn, T.C. and R.J. Faber, 1989. Compulsive buying: A phenomenological exploration. Journal of Consumer Research, 16(2): 147-158.

Ossebaard, H.C. and G.F. van de Wijngaart, 1998. Purple haze: The remaking of dutch drug policy. International Journal of Drug Policy, 9: 263-271.

Patton, M.Q., 1990. Newbury Park, CA: Sage Publications.

Robinette, S., L. Jr, V., D. Hall, C. Brand and D. Jr Hall, 2000. Emotion Marketing: The Hallmark Way of Winning Customers for Life, McGraw-Hill, New York, NY, In Harris, L. C., \& K. L. Reynolds, 2004. Jaycustomer behavior: An exploration of types and motives in the hospitality industry. The Journal of Services Marketing, 18: 339-357.

Salles, C., 1998. The other side of antiquity. The Felonry. (K. Tsitarakis trans.), Eds. Papadima, A thens.

Schneider, B. and D.E. Bowen, 1995. Winning the service game, Harvard Business School Press, Boston, MA, In Harris, L. C., \& K. L. Reynolds, 2004. Jaycustomer behavior: An exploration of types and motives in the hospitality industry. The Journal of Services Marketing, 18: 339-357. 
Scott, B., 1998. Workplace violence in the UK hospitality industry: impacts and recommendations. Progress in Tourism and Hospitality Research, 4: 337-347.

Sennewald, C., 1985. Effective security management. Butterworth-Heinemann, Newton, M.A.

Simonsen, C., 1996. The case for: Security management is a profession. International Journal of Risk and Crime Prevention, 1(3): 229-232.

Stake, R.E., 1995. The art of case study research. London: Sage Publications.

Strutton, D., S.J. Vitell and L.E. Pelton, 1994. How consumers may justify inappropriate behavior in market settings: An application on the techniques of neutralization. Journal of Business Research, 30(2): 253-260.

Theoharis, N., 2007. Front Office Management, ed. Propombos, Athens (in Greek).

Tonglet, M., 2001. Consumer misbehaviour: An exploratory study of shoplifting. Journal of Consumer Behavior, 1(4): 336-354.

Webster, F.E., 1994. Market driven management. London: Wiley.

Wiersema, F., 2001. The New Market Leaders: Who's Winning and How in the Battle for Customers, New York: Free Press.

Yagil, D., 2008. When the customer is wrong: A review of research on aggression and sexual harassment in service encounters. Aggression and Violent Behavior, 13(2): 141-152. 